\title{
Development and Growth: Influence of Sowing Dates on Performance of Cotton Cultivars
}

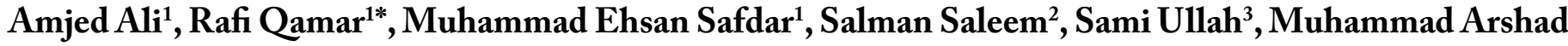 \\ Javed $^{4}$ and Syed Wasim Hasan ${ }^{5}$
}

${ }^{1}$ Department of Agronomy, College of Agriculture, University of Sargodha, Pakistan; ${ }^{2}$ Maize, Sorghum, Millet and Fodder Program CSI, NARC, Islamabad, Pakistan; ${ }^{3}$ Applied Statistics, College of Agriculture, University of Sargodha, Pakistan; ${ }^{4}$ Department of Agricultural Extension, College of Agriculture, University of Sargodha, Pakistan; ${ }^{5}$ Department of Plant Breeding and Genetics, College of Agriculture, University of Sargodha, Pakistan.

Abstract | Agriculture has a principal impact on Pakistan's economy since its existence. The cotton crop is considered the backbone of agriculture and research are mandatory to augment its production. Indigenous cultivars have an impressive production potential while climatic sowing dates fluctuation during crop planting is the leading hindrance in its production. Therefore, this one-year field experiment was performed to assess the result of varying cultivars and sowing dates on developmental and allometric traits of cotton (Gossypium birsutum L.) under the agro-ecological conditions at Sargodha, Punjab, during Kharif season, 2015. The study consisted of i) three cultivars viz. Bt. FH-142, Bt. MNH-886 and FDH-170 and ii) three sowing dates viz. $21^{\text {st }}$ April, $5^{\text {th }}$ May and $20^{\text {th }}$ May. Cultivars and sowing dates improved developmental and allometric traits of cotton in the study year. Significantly, $21^{\text {st }}$ April cotton sowing observed maximum days taken from planting to first flower and boll opening, fruiting branch and branch height (65.02), (112.56), (10.02) and $(26.43 \mathrm{~cm})$ in FDH-170, respectively while boll maturation (48.05) was noted in Bt. MNH886. Sowing date $5^{\text {th }}$ May plot recorded more leaf area index and net assimilation rate in FDH-170 (4.45 and $3.87 \mathrm{~g} \mathrm{~m}^{-2}$ day $\left.{ }^{1}\right)$ while leaf area duration and crop growth rate in Bt. FH-142 (282.32 and $\left.6.67 \mathrm{~g} \mathrm{~m}^{-2} \mathrm{day}^{-1}\right)$, respectively. Significantly, higher TDM production was recorded on 21 $1^{\text {st }}$ April in Bt. FH-142 (1104.33 $\left.\mathrm{g} \mathrm{m}^{-2}\right)$. Therefore, cotton should be grown among after $15^{\text {th }}$ April to before $10^{\text {th }}$ May with cultivars FHD-170, Bt. FH-142 and Bt. MNH-886 respectively under semi-arid conditions of Pakistan.

Received | August 20, 2017; Accepted | November 20, 2020; Published | February 07, 2021

*Correspondence | Rafi Qamar, Department of Agronomy, College of Agriculture, University of Sargodha, Pakistan; Email: drrafi1573@gmail. com

Citation | Ali, A., R. Qamar, M.E. Safdar, S. Saleem, S. Ullah, M.A. Javed and S.W. Hasan. 2021. Development and growth: influence of sowing dates on performance of cotton cultivars. Pakistan Journal of Agricultural Research, 34(1): 23-28.

DOI | http://dx.doi.org/10.17582/journal.pjar/2021/34.1.23.28

Keywords | Cotton, Sowing dates, Cultivars, Crop growth and development, Leaf area index

\section{Introduction}

$\mathrm{C}^{\mathrm{s}}$ otton (Gossypium birsutum L.) plant is recognized as white gold and warm humid area of the world under its cultivation (Meredith et al., 1997). In the world, Pakistan ranked $3^{\text {rd }}$ being a consumer and fourth in terms of production (GoP, 2015-16). It has a leading role in Pakistan's economy as a main cash crop.
Moreover, foreign exchange earnings and support about 1.5 million rural economies (Hussain et al., 2010; Ahmad et al., 2009). Cotton crop share in value addition is $5.1 \%$ and in gross domestic production is 1.0\% (GoP, 2015-16). Recent economic importance of cotton is 2.917 million hectares' areas with total production and average yield are 10.074 million bales and $587 \mathrm{~kg}$ per hectare, respectively (GoP, 2015-16). 
It is the only main fiber crop of Pakistan however, its area under cultivation and production is lower than other cotton producing states of the world owing to continuous ambitious exertions of scientist in field of breeding and production (Ali et al., 2005). There are several reasons like climatic/environmental, soil, water shortage and crop husbandry which are continuously creating a hindrance in cotton production. Among yield reducing factors, sowing time is one of major the agronomic factor which additively restricting the cotton growth and production by affecting yield related parameters.

Date of sowing dependent on mean maximum and minimum temperature which directly upsets cotton crop growth and yield that ultimately affect the fiber quality. Moreover, results revealed that one week delayed in sowing clearly reduced the cotton yield by influencing its growth and yield parameters (Abdel-Malak et al., 1996). Temperature variations in different agro-ecological zones of Pakistan, it is necessary to research on appropriate sowing time for recommendation of cotton sowing in order to enhance its production (Kakar et al., 2012). Moreover, climatic variations influenced the regional sowing calendar which determined the time of vegetative and reproductive stage of the crop. Cotton is a temperature sensitive crop and its production is drastically reduced by too early and too late sowing time (Bange and Milroy, 2004). It was experimented that appropriate sowing time improved the cotton yield by positively shape the growth and developmental stages (Soomro et al., 2001). Moreover, it was perceived and recommended that $15^{\text {th }}$ April to $1^{\text {st }}$ May cotton crop sowing responded better growth and yield rather than first week of April to end of May (Arain et al., 2001). Deviation from appropriate sowing date/time brings a significantly changed in fiber quality and yield attributes viz., ginning out turn (\%), fiber length, number of bolls and weight and and seed cotton weight (Niazi, 2005).

As discussed above, cotton sowing is temperature sensitive step and seeded in a wide range of agroecological zones. However, selection of appropriate sowing date for different cultivars under different regions is the key factor for getting maximum cotton production (Bozbek et al., 2006). Different cultivars differ in the characteristics of fiber quality (Mohammad, 2001) and responded differently under different temperature regimes (Killi et al., 2005).
Hence, appropriate sowing dates and cultivars have mark able effect on fiber quality and oil content traits (Iqbal and Khan, 2011). Most of the cotton cultivars exhibited better performance in terms of growth and yield up to $15^{\text {th }}$ April as compared with late sowing beyond $1^{\text {st }}$ June (Siddiqui et al., 2004).

A field study was designed to test which cultivars performed better in developmental and allometric features as sown under different dates in semi-arid region of Pakistan.

\section{Materials and Methods}

\section{Study site}

To evaluate the effect of cotton (Gossypium hirsutum L.) sowing date on cultivars growth and development was studied through field experiments executed at research area of College of Agriculture, University of Sargodha, Sargodha, Pakistan, during Kharif season, 2015. The experimental area was located at $32.08^{\circ} \mathrm{N}$ and $72.67^{\circ} \mathrm{E}$ and altitude $193 \mathrm{~m}$. The soil of experimental site was sandy clay loam.

\section{Experimental design, treatments and cultural practices}

Statistically RCBD with split plot arrangement was used having 03 replications while the net dimension of experimental unit was $6.0 \mathrm{~m} \times 4.5 \mathrm{~m}$. Three cultivars $\left(\mathrm{C}_{1}=\right.$ Bt.FH-142, $\mathrm{C}_{2}=$ Bt.MNH-886, $\left.\mathrm{C}_{3}=\mathrm{FDH}-170\right)$ were randomized in the main plots while three sowing dates $\left(\mathrm{SD}_{1}=21^{\text {st }}\right.$ April, $\mathrm{SD}_{2}=5^{\text {th }}$ May, $\mathrm{SD}_{3}=20^{\text {th }}$ May) were applied in subplots. After wheat crop harvest, the soil was prepared for cotton crop by disking twice in order to break soil clods and fine texture. Single row hand drill was used for cotton sowing by maintaining $\mathrm{R} \times \mathrm{R}$ distance $75 \mathrm{~cm}$ and seed @ of $20 \mathrm{~kg} \mathrm{ha}^{-1}$ was used. At the time of soil preparation, whole dose of phosphorous and potassium were incorporated while nitrogen was applied in three splits $1^{\text {st }}$ at sowing, $2^{\text {nd }}$ at first irrigation and $3^{\text {rd }}$ at second irrigation. Moreover, uniform agronomic practices were applied in all the experimental units.

\section{Methodology of developmental and growth parameters to be measured}

Developmental and growth parameters of cotton, including first flower and boll opening, boll maturation, first fruiting branch and height $(\mathrm{cm})$, leaf area index (LAI), total dry matter (TDM) $\left(\mathrm{g} \mathrm{m}^{-2}\right)$, leaf area duration (LAD), crop growth rate (CGR) $\left(\mathrm{g} \mathrm{m}^{-2} \mathrm{day}^{-}\right.$ $\left.{ }^{1}\right)$ and net assimilation rate (NAR) $\left(\mathrm{g} \mathrm{m}^{-2} \mathrm{day}^{-1}\right)$. Crop 
developmental parameters data were recorded after sowing. For this purpose, ten plants were selected and their averages were taken to calculate days taken to first flower and boll opening, boll maturation (days), first fruiting branch and height $(\mathrm{cm})$. Leaf lamina of $5 \mathrm{~g}$ sample from each plot was taken and measured leaf area by using formula of Watson (1952) through operating CI-202. Portable Laser Leaf Area Meter.

\section{$L A I=$ Leaf area $/$ land area}

For total dry matter, $50 \mathrm{~g}$ fresh sample was harvested from each treatment than sun dried it for 3-4 days. After sun dried, sample was placed in oven for three days at $72{ }^{\circ} \mathrm{C}$. Then dried leaves were weighed for calculating of total dry matter. For this purpose, weight of $1 \mathrm{~m}$ length of dried plants were converted into per square meter and then into per hectare. LAD, CGR and NAR were calculated by using Hunt (1978) formula respectively.

$$
\begin{gathered}
L A D=\left(L A I_{1}+L A I_{2}\right) / 2 \times\left(t_{2} t_{1}\right) \\
C G R\left(g m^{-2} d a y^{-1}\right)=\left(W_{2}-W_{1}\right) /\left(t_{2}-t_{1}\right) \\
N A R\left(g m^{-2} d a y^{-1}\right)=T D M / L A D
\end{gathered}
$$

\section{Statistical analysis}

Data of the experiment was statistically analyzed $\mathrm{p} \leq$ 0.05 by using SAS (SAS Institute, 2008) to evaluate the response of cotton cultivars under different sowing dates. Graphical presentation of data was calculated using R software (R Core Team, 2012).

\section{Results and Discussion}

\section{Influence of sowing dates on phenological attributes of cotton cultivars}

Sowing date had significant effect on development and growth parameters of cotton cultivars during year of study (Figures 1 and 2). Outcome of sowing dates on developmental attributes of cotton cultivars were depicted in Figure 1. Sowing date $21^{\text {st }}$ April produced maximum (65.02) first flower opening in FDH-170 while minimum flowers opening were observed on $20^{\text {th }}$ May in all cotton cultivars. Likewise, maximum days taken to open first boll was noted on $21^{\text {st }}$ April in FDH-170 (112.56). Moreover, cultivars sown on May, $20^{\text {th }}$ showed minimum (108.34) days taken to first boll opening for FDH-170. Similarly, significantly maximum (48.05) days for boll maturation was recorded on April, $21^{\text {st }}$ in Bt. MNH886, followed by FDH-170 and Bt. FH-142 while minimum was noted at $5^{\text {th }}$ May and $20^{\text {th }}$ May all cultivars respectively. Maximum number (10.12) of nodes from first fruiting branch was recorded at $21^{\text {st }}$ April in FDH-170 while minimum number of nodes was noted at $20^{\text {th }}$ May in all cultivars. Significantly first fruiting branch height $(27.63 \mathrm{~cm})$ was verified on $21^{\text {st }}$ April sowing in FDH-170. Cultivars sown May, $20^{\text {th }}$ produced shorter first fruiting branch and height in FDH-170 $(25.67 \mathrm{~cm})$ followed by Bt. FH$142(23.42 \mathrm{~cm})$ and Bt. MNH-886 $(22.95 \mathrm{~cm})$.
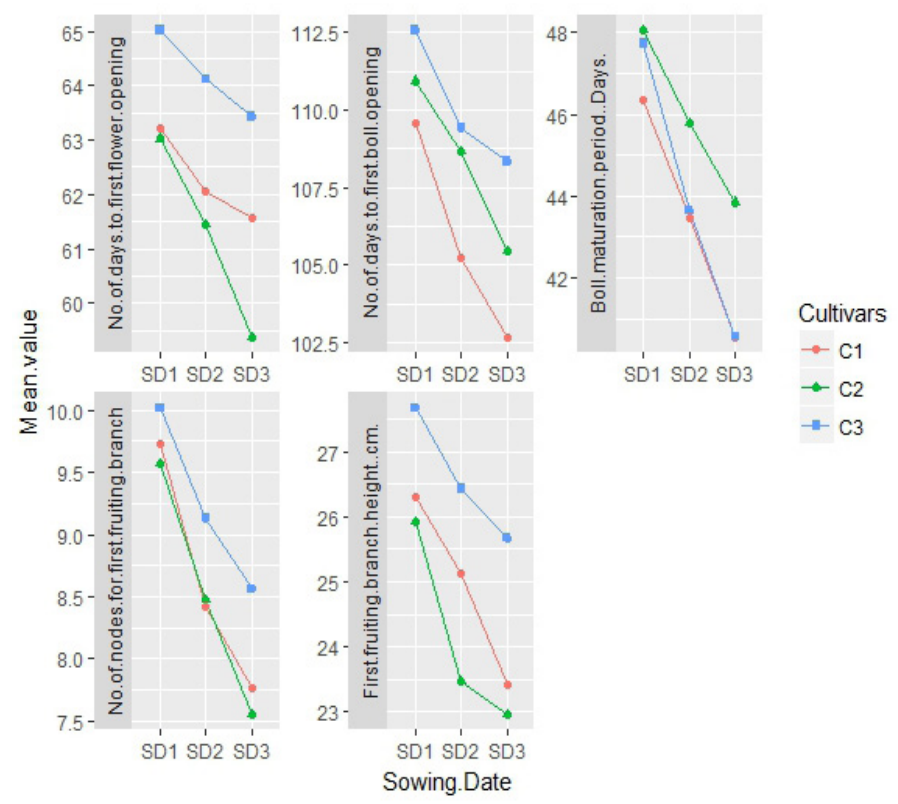

Figure 1: Influence of sowing dates on developmental attributes of cotton cultivars
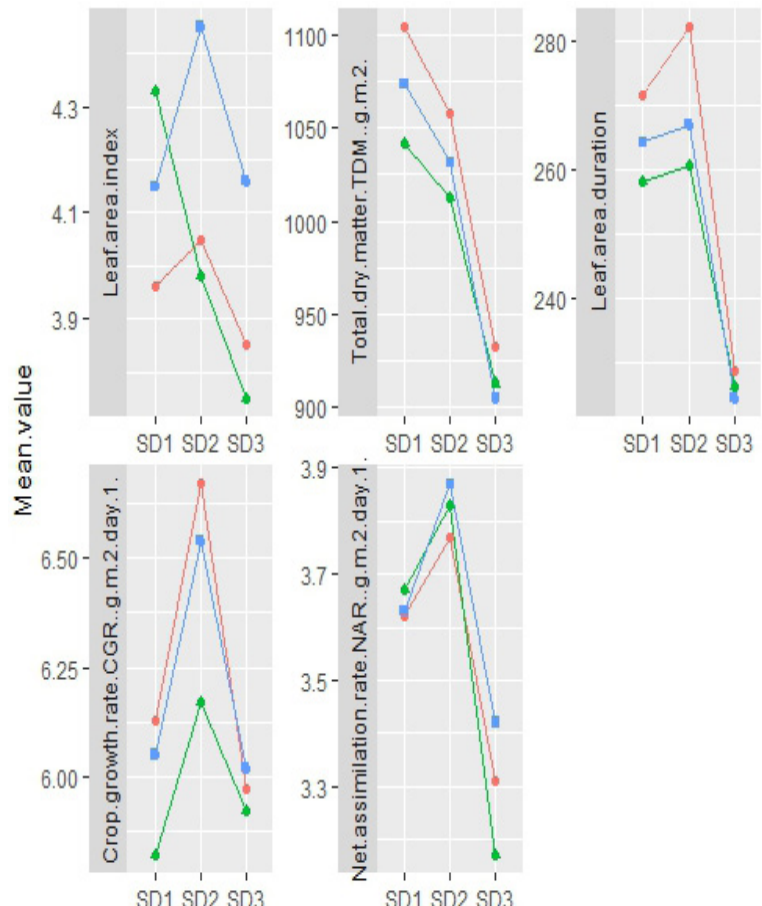

Cultivars

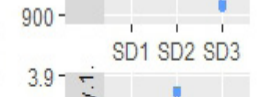

SD1 SD2 SD3
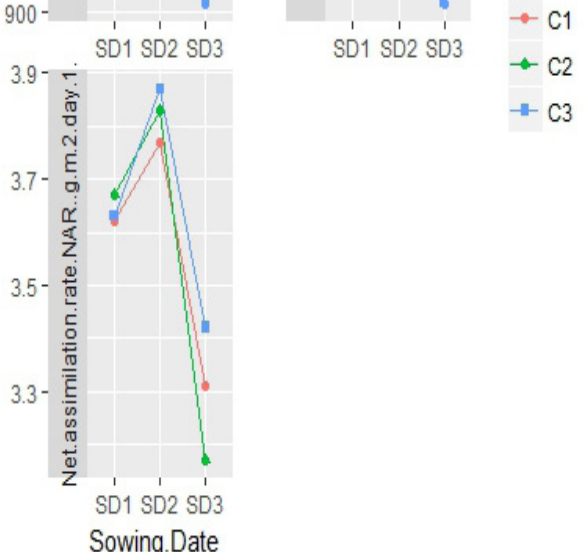

$\rightarrow \mathrm{C} 2$

$-\mathrm{C} 3$

Figure 2: Influence of sowing dates on growth attributes of cotton cultivars. 
Results revealed that cotton developmental and growth stages showed sensitivity to different sowing dates. Early plantation of cotton cultivars responds positively to developmental parameters (Pettigrew and Johnson, 2005). Suitable environmental conditions are available to crop plants when planted in the month of April which brings improvement in the developmental stages and reduced the risk of flower and boll opening. Late planting resulted in significant reduction in boll maturation due to high temperature and ultimately reduced the cotton yield (Butter et al., 2004). Early sowing crop enjoy better agro-resources which protect the primary fruiting branch nodes and height in cotton cultivars from hot humid weather that cause fruit losses (Ali et al., 2009). In our study, early sown cotton improved their developmental stages which may be efficient utilization of moisture and nutrients in the semi-arid arid region. Moreover, late sown crop showed lower developmental parameters like days to flower and boll opening and maturation and nodes for first fruiting branch and height might be due to high temperature at early growth stages and short time. Appropriate sowing time enhanced the cotton yield due to prolong period of flowering before the start of any stress and healthy plants improved the efficiency of nutrient and moisture uptake which was helpful during boll formation and maturation (Arian et al., 2001; Tahir et al., 2009). Moreover, optimum sown cotton enjoys the sufficient soil nutrients and moisture due to prolonged stay in field which resulted in formation of maximum floral buds and boll maturation due to optimum growing degree-days (Gormus et al., 2002). Ali and El-Sayed (2001) reported that cotton cultivars showed positive response to early sowing which resulted in substantial increase in boll opening, boll maturation and days taken to first flower and boll open.

Influence of sowing dates on growth attributes of cotton cultivars

Influence of sowing dates on growth parameters of cotton cultivars were depicted in Figure 2. It is recorded that FDH-170 responded significantly (4.45) maximum leaf area index at $05^{\text {th }}$ May than Bt. FH-142 and Bt. MNH-886 at $21^{\text {st }}$ April and $20^{\text {th }}$ May respectively. Sowing date $21^{\text {st }}$ April produced maximum (1104.33 $\mathrm{g} \mathrm{m}^{-2}$ ) total dry matter in Bt. FH-142 while significantly minimum TDM were observed on $20^{\text {th }}$ May in all cotton cultivars. Moreover, Bt. FH-142 showed maximum (282.32) leaf area duration on $05^{\text {th }}$ May sowing while minimum
(224.57) leaf area duration was recorded in $20^{\text {th }}$ May sowing in all cultivars. Similar trend was recorded in case of crop growth rate in which Bt. FH-142 respond significantly $\left(6.67 \mathrm{~g} \mathrm{~m}^{-2}\right.$ day $\left.^{-1}\right)$ maximum in $05^{\text {th }}$ May sown crop. Significantly higher value of NAR (3.87 $\mathrm{g} \mathrm{m}^{-2}$ day $\left.^{-1}\right)$ was perceived on $05^{\text {th }}$ May sown in FDH-170 cultivar while lower $\left(3.17 \mathrm{~g} \mathrm{~m}^{-2}\right.$ day $^{-1}$ ) for NAR was documented when sown on May, $20^{\text {th }}$ in all cultivars.

Cotton growth parameters are very sensitive to temperature fluctuation and directly influenced by planting time (leaf area index, total dry matter and days taken to flowering) (E1-Hindi et al., 2006). Our study results supported the findings of Gecgel et al. (2007) who found that optimum sowing dates had significantly and positively improves the plant growth. Moreover, optimum sowing is a key element for positive enhancement in growth and cotton crop growth tend to decrease when sowing was done at late (Bozbek et al., 2006). The joint opinion regarding sowing date effect is that the appropriate planting improves the cotton growth that have indeterminate growth habit. Therefore, timely sowing acquires maximum growth time, leaf area index, leaf area duration which improved radiation interception that resulted in maximum total dry matter production (Akhter et al., 2002). Ullah et al. (2015) recorded that $15^{\text {th }}$ April to $1^{\text {st }}$ May sown cotton gave maximum total dry matter, leaf area index and duration whereas too late or early sown crop showed minimum growth parameters as they receive less units of heat. Research on cotton sowing date had been concise by the researchers and they are agreed that late sown cotton resulted in cotton growth reduction due to short growing period (Bange et al., 2008). Our finding in accordance with study of Siddiqui et al. (2004) they found that April to May sown crop showed maximum total dry matter production which enhances the growth rate and net assimilation rate than late sown. Similarly, fortnightly delay in sowing beyond $20^{\text {th }}$ April resulted in a significant reduction in growth due to high temperature (Poonia et al., 2002). Moreover, sowing in months of March to April gave significant effects on growth like LAI, LAD, TDM and NAR (Butter et al., 2004).

\section{Conclusions and Recommendations}

Study showed that cotton cultivars strongly influenced by the change in sowing date. Late sown 
cotton resulted in significant reduction in growth and developmental parameters. Therefore, smooth growth rate was achieved when cotton crop sowing was completed from last week of April to first week of May by using Bt. FH-142 cultivars than other cultivars.

\section{Novelty Statement}

Cotton cultivar's performance were evaluated in semiarid region instead of tropical region of Pakistan.

\section{Author's Contribution}

Amjed Ali: Conceived the idea, overall management of the article data collection.

Rafi Qamar: Wrote abstract, introduction, methodology, result and discussion, conclusion, overall management of the article.

Muhammad Ehsan Safdar: Overall management of the article.

Salman Saleem: Technical input at every step.

Semi Ullah: Data entry and analysis.

Muhammad Arshad Javed: Wrote abstract and conclusion.

Syed Wasim Hasan: Technical input at every step.

\section{Conflict of interest}

The authors have declared no conflict of interest.

\section{References}

Abdel-Malak, K.K.I., E.A. Makram and M.M. Razaz. 1996. Effect of hill spacing and nitrogen levels in relation to planting dates on growth and yield of Giza-83 Cotton variety. Assiut. J. Agric. Sci., 27: 155-168.

Ahmad,A.U.H.,R.Ali,S.I.Zamir and N.Mahmood. 2009. Growth, yield and quality performance of cotton cultivars BH-160 (Gossypium birsutum L.) as influenced by different plant spacing. J. Anim. Plant Sci., 19: 189-192.

Akhter, M., M.S. Cheema, M. Jamil, S.A. Shahid and M.I. Shahid. 2002. Response of cotton genotypes to time of sowing. Asian J. Plant Sci., 1: 538-539. https://doi.org/10.3923/ ajps.2002.538.539

Ali, A., G.M. Aheer, M. Saleem, Zafar-ullahShah, M. Ashfaq and M.A. Khan. 2009. Effect of sowing dates on population development of Helicoverpa armigera $(\mathrm{Hb}$.) in cotton genotypes.
Pak. Entomol., 31: 128-132.

Ali, H., D. Muhammad, M.N. Aftzal and S.A. Abid. 2005. Seed cotton yield of different cultivars as affected by sowing time under agroclimatic conditions of southern Punjab. Indus Cotton, 2: 186-189.

Ali, S.A. and A.F. El-Sayed. 2001. Effect of sowing date and nitrogen levels on growth, earliness and yield of Egyptian cotton cultivar Giza 88. Egypt J. Agric. Res., 79: 221-232.

Arain, M.H., S. Arain, M.J. Baloch, G.H. Kalwar and A.A. Memon. 2001. Performance of newly developed cotton strain under different sowing dates. Pak. J. Biol. Sci., 1(Suppl.): 1-2.

Bange, M.P., S.J. Caton and S.P. Milroy. 2008. Managing yields of high fruit retention in transgenic cotton (Gossypium birsutum L.) using sowing date. Aust. J. Agric. Res., 59: 733-741. https://doi.org/10.1071/AR07423

Bange, M.P. and S.P. Milroy. 2004. Growth and dry matter partitioning of diverse cotton genotypes. Field Crops Res., 87: 73-87. https://doi. org/10.1016/j.fcr.2003.09.007

Bozbek, T., V. Sezener and A. Unay. 2006. The effect of sowing date and plant density on cotton yield. J. Agron., 5: 122-125. https://doi. org/10.3923/ja.2006.122.125

Butter, G.S., N. Aggarwal and S. Singh. 2004. Productivity of American cotton as influenced by sowing date. Haryana J. Agron., 20: 101-102.

El-Hindi, M.H., E.M. Said, M.H. Ghonema and A.F. Khalifa. 2006. Studies on the effect of some cultural practices on the growth and the yield of Egyptian cotton. J. Agric. Sci. Mansoura Univ., 31: 4087-4095.

Gecgel, U., M. Demirci and E. Esendal. 2007. Fatty acid composition of the oil from developing seeds of different varieties of safflower (Carthamus tinctorius L.). J. Am. Oil Chem. Soc., 84: 47-54. https://doi.org/10.1007/s11746-006-1007-3

Gormus, O. and C. Yucel. 2002. Different planting dates and potassium fertility effects on cotton yield and fiber properties in the Cukurova region, Turkey. Field Crop Res., 78: 141-149. https:// doi.org/10.1016/S0378-4290(02)00121-1

GoP, 2015-16. Economic survey of Pakistan. Finance division economic advisor's wing, Islamabad.

Hunt, R., 1978. Plant growth analysis. Edward Arnold U.K. pp. 26-38.

Hussain, S., N.N. Nawab, M.A. Ali, A. Hussain, 
M.A. Nawaz and T.A.Malik. 2010. Evolution of performance, genetic divergence and character association of some polygenic traits in upland cotton. J. Agric. Soc. Sci., 6: 79-82.

Iqbal, M. and M.A. Khan. 2011. Response of cotton genotypes to planting date and plant spacing. Front. Agric. in China, 5: 262-267. https://doi. org/10.1007/s11703-011-1099-x

Kakar, N.U., F.C. Oad, S. Tunio, Q.U. Chachar and M.M. Kandhro. 2012. Response of sowing time to various cotton genotypes. Sarhad J. Agric., 28: 379-385.

Killi, F., L. Efe and S. Mustafayev. 2005. Genetic and environmental variability in yield, yield components and lint quality traits of cotton. Int. J. Agric. Biol., 7: 1007-1010.

Meredith, W.R., J.J. Heitholt, W.T. Pettigrew and S.T. Rayburu. 1997. Comparison of obsolete and modern cotton cultivars at two nitrogen levels. Crop Sci., 37: 1453-1457. https://doi.org/10.2135/ cropsci1997.0011183X003700050006x

Mohammad, J.B., 2001. Stability and adaptability analysis of some quantitative traits in upland cotton varieties. Pak. J. Sci. Ind. Res., 44: 105108.

Niazi, S.K., 2005. Response of cotton varieties to different sowing dates. M.Sc. (Hons.) thesis Dept. Agron. Sindh Agric. University of Tandojam, Pakistan. pp. 1-59.

Pettigrew, W.T. and J.T. Johnson. 2005. Effects of different seeding rates and plant growth regulators on early-planted cotton. J. Cotton Sci., 9: 189-198.
Poonia, B.L., R.P. Singh and N.K. Jain. 2002. Response of upland cotton (Gossypium birsutum L.) cultivars to different dates of planting. Indian J. Agric. Sci., 72: 171-173.

R Core Team,2012. R: A language and environment for statistical computing. R Foundation for Statistical Computing, Vienna, Austria. ISBN 3-900051-07-0, http://www.R-project.org.

SAS Institute, 2008. SAS online doc 9.13. SAS Institute, Inc., Cary, NC.

Siddiqui, M.H., F.C. Oad and A.N. Shah. 2004. Dry matter accumulation in various parts of cotton genotypes as affected by sowing dates. Asian J. Plant Sci., 3: 262-263. https://doi. org/10.3923/ajps.2004.262.263

Soomro, A.R., R. Anjum, A.W. Soomro, A.M. Memmon and S. Bano. 2001. Optimum sowing time for new commercial cotton variety, Marvi. (CRIS-5A). Pak. Cottons, 45: 25-28.

Tahir, M., A. Ali, M.A. Nadeem, A. Hussain and F. Khalid. 2009. Effect of different sowing dates on growth and yield of wheat (Triticum aestivum L.) varieties in district Jhang, Pakistan. Pak. J. Life Soc. Sci., 7: 66-69.

Ullah, K., N. Khan, Z. Usman, R. Ullah, F.Y. Saleem, S.A.I. Shah and M. Salman. 2015. Impact of temperature on yield and related traits in cotton genotypes. J. Integ. Agric., 15: 61088-61097. https://doi.org/10.1016/S20953119(15)61088-7

Watson, D.J., 1952. The physiological basis of variation in yield. Adv. Agron., 4: 101$145 . \quad$ https://doi.org/10.1016/S00652113(08)60307-7 